\title{
Range expansion and parasitism in the nonnative snail Radix auricularia
}

\author{
Michele D. LARSON ${ }^{1, *}$ \\ ${ }^{1}$ University of Wyoming, Department of Zoology and Physiology, Program in Ecology, Laramie, WY 82072
}

\begin{abstract}
The nonnative snail Radix auricularia was found at 4 previously unknown locations in Wyoming. At Two Ocean Lake in Grand Teton National Park, R. auricularia was found with trematode infections that were the same cercarial type found in native snails during the same sampling period. Although finding parasitic infections in a nonnative species challenges the enemy release hypothesis, the presence of trematodes in $R$. auricularia may act to suppress population growth of this snail, thereby emolliating the negative impact this snail may have on native populations. Further research assessing the prevalence of trematode parasites in $R$. auricularia would aid in understanding whether this nonnative snail harbors parasites across its invasive range, which could have ramifications for parasitism of local waterfowl and wildlife in these habitats.
\end{abstract}

Resumen.-Encontramos al caracol no nativo Radix auricularia, en cuatro sitios no reportados anteriormente en Wyoming. En el Lago Two Ocean del Parque Nacional Grand Teton, R. auricularia presentó infecciones causadas por trematodos, iguales a las infecciones encontradas en los caracoles nativos durante el mismo período de muestreo. A pesar de que, encontrar infecciones parasitarias en especies no nativas desafía la hipótesis de la liberación del enemigo (ERH, por sus siglas en inglés), la presencia de trematodos en $R$. auricularia puede actuar para disminuir su crecimiento poblacional, reduciendo el posible impacto negativo que tiene en poblaciones nativas. Investigación futura, que evalúe la prevalencia de los parásitos trematodos en $R$. auricularia podría ayudar a comprender si este caracol no nativo alberga parásitos a lo largo de su rango invasivo que promueva el parasitismo de aves acuáticas locales y vida silvestre de estos hábitats.

In freshwater ecosystems, invasive gastropods threaten the diversity of native gastropods (Lydeard et al. 2004). Invasive gastropods can outcompete native gastropods for food resources (Strayer 1999, Brown et al. 2008, Riley et al. 2008, Hendrickx et al. 2015, Larson and Black 2016); bring parasites to new ecosystems or act as alternative hosts for native parasites, which may increase parasitic infections in native gastropods (Torchin and Mitchell 2004, Mastitsky et al. 2010, Karatayev et al. 2012, Gérard et al. 2017); and alter nutrient cycling, which may influence the amount and type of food resources available to native gastropods (Hall et al. 2003, Arango et al. 2009). Yet, for many nonnative gastropods, little is known about their current distributions or impacts on native gastropods.

The European ear snail, Radix auricularia, is a nonnative gastropod in North America with limited research in invaded ecosystems, unknown and possibly expanding distributions, and little quantitative data on habitat requirements and possible impacts on other organisms including native gastropods. In the snail's native range (most of Europe and temperate Asia), multiple freshwater gastropod surveys indicate that $R$. auricularia can reside in a wide range of temperatures $\left(4\right.$ to $32{ }^{\circ} \mathrm{C}$ ), specific electrical conductivities $(200-1200 \mu \mathrm{S} / \mathrm{cm})$, and habitat types (slow-moving rivers and streams, ponds, reservoirs, and wetlands; Spyra 2010, Vinarski and Serbina 2012, von Oheimb et al. 2016). In some locations in its native range, $R$. auricularia can reach high population densities (accounting for 16\% to 54.4\% of snails based on abundance) forming monocultures and constituting a large snail biomass (19\%-23\%; Vinarski and Serbina 2012). Additionally, in Eastern Europe, R. auricularia is primarily studied as the host for avian schitosomes (Trichobilharzia szidati, T. ocellata, and

*Corresponding author: mlarso22@uwyo.edu 


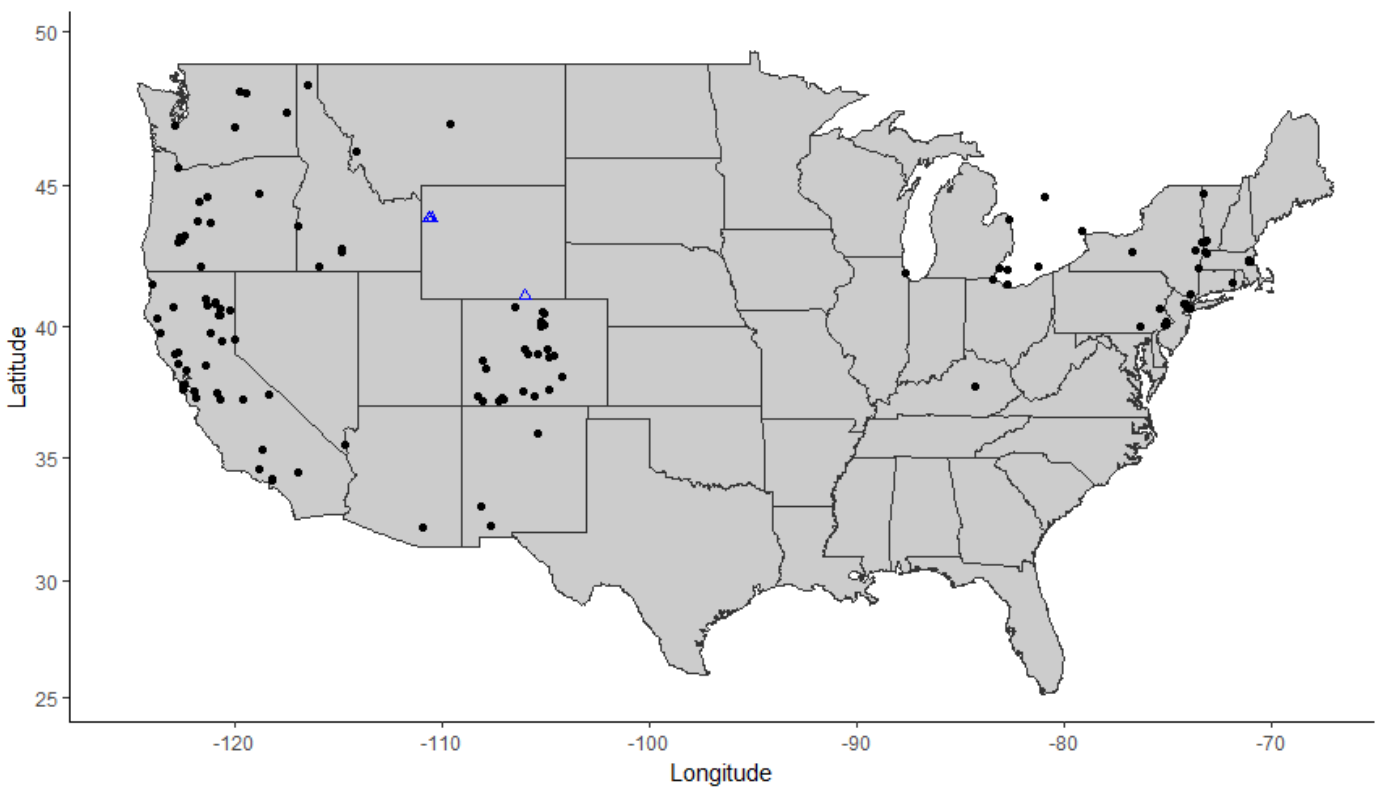

Fig. 1. Current range of the invasive snail Radix auricularia in the United States. Range data obtained from the USGS Invasive Species Database (Kipp et al. 2017) are shown as solid black circles, while new locations in Wyoming are shown as open blue triangles.

T. franki) which can negatively influence native waterfowl populations (Kolarova et al. 1997, Zbikowska 2004).

In North America, R. auricularia has been introduced across the United States to areas including the Hudson River area, the Great Lakes region, and at least 8 states (Colorado, Arizona, California, Idaho, Montana, New Mexico, Oregon, and Washington) in the western United States (Kipp et al. 2017). Yet, little research has been conducted on the distribution, habitat requirements, or possible negative impacts this nonnative snail may be having on native species. Here, I report the first occurrence of $R$. auricularia in Wyoming, as well as the first record of trematode parasites using this snail as a host in invaded ecosystems.

I conducted aquatic gastropod sampling at locations in the Greater Yellowstone Ecosystem (Grand Teton National Park, Yellowstone National Park, and Teton County, WY; $43.8^{\circ} \mathrm{N}$, $110.7^{\circ} \mathrm{W}$ ) in the summers of 2014 and 2015 . At each survey location, I collected native and invasive snails by hand or by using hand sieves (for a total of $2 \mathrm{~h}$ of sampling effort at each location). Using the same methods, I also collected snails from the Laramie River watershed $\left(41.1^{\circ} \mathrm{N}, 106.0^{\circ} \mathrm{W}\right)$ in Albany County, Wyoming, in September 2015.

All snails were identified to genus and examined for trematode infections. I conducted parasitological examinations of the snails by shedding and dissecting snails for trematode infections. To assay trematode prevalence (infection rate) in all snails, I placed individual snails in $30-\mathrm{mL}$ cups containing $20 \mathrm{~mL}$ of filtered water under a 60-W lightbulb for $2 \mathrm{~h}$. This method forces the release of the trematode larval stage (cercariae). Next, I dissected all infected snails under a dissecting microscope to confirm infection status and to assess the cercarial type of the trematodes. Trematodes were identified to cercarial type (the lowest possible taxonomic level for larval trematodes) using Schell (1970).

I found 4 previously unrecorded (based on USGS introduced species map; Kipp et al. 2017) locations with populations of $R$. auricularia in Wyoming (Fig. 1). Three locations occurred in Grand Teton National Park (Two Ocean Lake, Oxbow Lake, and Third Creek), while the fourth population was found in the Big Laramie River near Jelm, Wyoming. At all 4 locations, $R$. auricularia was found at low population densities (about 1 snail $/ \mathrm{m}^{2}$ ) in 
TABLE 1. Trematode prevalence and cercarial larval type found in different species of native snails and Radix auricularia at 4 locations in Wyoming. Cercarial larval type is the lowest taxonomic distinction for larval trematodes released from snails (Schell 1970).

\begin{tabular}{|c|c|c|c|c|c|}
\hline Year/location & Snail species & $\begin{array}{l}\text { No. of snails } \\
\text { collected }\end{array}$ & $\begin{array}{l}\text { No. of snails } \\
\text { infected }\end{array}$ & $\begin{array}{c}\text { Prevalence of } \\
\text { trematode infections }\end{array}$ & $\begin{array}{l}\text { Cercarial } \\
\text { type present }{ }^{\mathrm{a}}\end{array}$ \\
\hline \multicolumn{6}{|l|}{2014} \\
\hline \multirow[t]{3}{*}{ Oxbow Lake } & Lymnaea sp. & 67 & 6 & $9.0 \%$ & $\mathrm{ECH}$ \\
\hline & Physa sp. & 21 & 3 & $14.2 \%$ & FUR \\
\hline & R. auricularia & 1 & 0 & $0.0 \%$ & - \\
\hline \multirow[t]{2}{*}{ Third Creek } & Physa sp. & 12 & 1 & $8.3 \%$ & $\mathrm{ECH}$ \\
\hline & R. auricularia & 6 & 0 & $0.0 \%$ & - \\
\hline Big Laramie River & R. auricularia & 18 & 0 & $0.0 \%$ & - \\
\hline \multicolumn{6}{|l|}{2015} \\
\hline \multirow[t]{3}{*}{ Two Ocean Lake } & Physa sp. & 29 & 2 & $6.9 \%$ & MONO; XIPH \\
\hline & Planorbella sp. & 5 & 2 & $40.0 \%$ & $\mathrm{ECH}$ \\
\hline & R. auricularia & 10 & 4 & $40.0 \%$ & MONO; ECH \\
\hline
\end{tabular}

a Four cercarial types were found in different snails at different locations and include echinostome cercaria (ECH), furcocercaria (FUR), monostome cercaria (MONO), and xiphidocercaria (XIPH). A dash indicates that no infected snails were found for that snail species at that location.

slow-moving or stagnant water and in association with mud substrate and macrophytes.

I shed all R. auricularia specimens for parasites and found infections in 4 of 10 snails at Two Ocean Lake (Table 1). Infected snails harbored single infections of either echinostome or monostome cercaria. These 2 cercarial types were also found in the native snails, Planorbella sp. and Physa sp., during the same sampling period in Two Ocean Lake (Table 1). I did not find trematode infections in the 3 other populations of $R$. auricularia in Wyoming; however, the low sample sizes of $R$. auricularia (Table 1) at these locations makes determination of infection status unlikely unless the overall infection rate for the location is very high.

I identified 4 previously unknown locations for $R$. auricularia which are the first reported occurrences of this nonnative snail in Wyoming. The continued spread of $R$. auricularia is troublesome due to the lack of research on this species in North America and the possible negative impacts this snail may have on native species. Radix auricularia has been shown to compete with native pond snails (Lymnaea sp.) in permanent lentic environments (Adam and Lewis 1992). Therefore, $R$. auricularia may reduce resources for native snails and other grazing macroinvertebrates if this nonnative snail reaches high population sizes (as occurs in its native range; Vinarski and Serbina 2012) in invaded ecosystems.

My study also found the first recorded trematode infections in $R$. auricularia in North America. The prevalence of $40 \%$ in Two Ocean Lake is substantially higher than prevalence values reported in the snail's native range (<5\%; Kolarova et al. 1997, Zbikowska 2004). This may be due in part to the small sample size $(n=10)$ but may also indicate that trematodes are selectively infecting $R$. auricularia. I found that $R$. auricularia was infected with 2 cercarial types that were also found in native snails (Table 1 ). This may suggest that $R$. auricularia is acting as a host for native trematodes; however, determining the origins of these parasites as native to Wyoming and using $R$. auricularia as a host, or native to Europe and brought to the United States inside $R$. auricularia, was not possible and would require genetic analysis of the trematodes to definitively state their origins. In either situation, the presence of an additional host for trematodes may have negative impacts for local waterfowl and wildlife because trematodes complete their life cycle in vertebrate hosts.

The presence of trematodes in the Two Ocean Lake populations of $R$. auricularia is unexpected but may explain the low population densities of $R$. auricularia found in many locations. Finding introduced snails with trematode infections is rare (Adema et al. 2009, Ladd and Rogowski 2012, Harried et al. 2015) and this lack of parasites (which often castrate snail hosts thereby significantly reducing the snail's fitness; Baudoin 1975) is often stated as a reason for the invasion success of nonnative snails (via the enemy release hypothesis; Vilà et al. 2005, Davies 2009, Roy and Lawson-Handley 2012). My observations of infected $R$. auricularia in Two Ocean Lake does not negate the enemy release hypothesis 
for other invasive snail species but may explain why $R$. auricularia is often considered a nonnative species instead of an invasive species. If trematode infections in $R$. auricularia are common across the introduced range of this snail, the parasites may be suppressing $R$. auricularia populations to low enough levels to reduce or eliminate any negative impacts associated with this nonnative snail.

The presence of $R$. auricularia in Wyoming shows an expansion of this nonnative snail's range, and the presence of trematode parasites in these snails may indicate a natural control method occurring in this nonnative species that may be reducing the impacts of this snail on native species. Additional research into the prevalence of trematode infections across the invasion range of this species will aid in assessing the importance of parasitism in controlling populations of $R$. auricularia.

\section{ACKNOWLEDGMENTS}

I thank D. Greenwood and K. Wise for assistance in collecting snails at field locations and aid in parasite processing. I am grateful to A. Krist for use of laboratory and field equipment and C. Adema for email conversations on identifying trematode cercarial types. I am also grateful to R. Walker and one anonymous reviewer for comments that improved this paper. I also thank my funding sources: The Meg and Bert Raynes Wildlife Fund and The Grant to Malacology from the Conchologists of America.

\section{Literature Cited}

ADAM, M.E., AND J.W. LEWIS. 1992. The lack of co-existence between Lymnaea peregra and Lymnaea auricularia (Gastropoda: Pulmonata). Journal of Molluscan Studies 58:227-231.

Adema, C.M., C.M. Lun, B. Hanelt, and R.S. Seville. 2009. Digenean trematode infections of native freshwater snails and invasive Potamopyrgus antipodarum in the Grand Teton National Park/John D. Rockefeller Memorial Parkway area. Journal of Parasitology 95:224-227.

Arango, C.P., L.A. Riley, J.L. Tank, and R.O. Hall Jr. 2009. Herbivory by an invasive snail increases nitrogen fixation in a nitrogen-limited stream. Canadian Journal of Fisheries and Aquatic Science 66: 1309-1317.

BAudoin, M. 1975. Host castration as a parasitic strategy. Evolution 29:335-352.

Brown, K.M., B. Lang, and K.E. Perez. 2008. The conservation ecology of North American pleurocerid and hydrobiid gastropods. Journal of the North American Benthological Society 27:484-495.
DAVIES, M.A. 2009. Invasion biology. Oxford University Press, Oxford, England.

Gérard, C., O. Miura, J. Lorda, T.H. Cribb, M.J. Nolan, AND R.F. HEChInGER. 2017. A native-range source for a persistent trematode parasite of the exotic New Zealand mud snail (Potamopyrgus antipodarum) in France. Hydrobiologia 785:115-126.

Hall, R.O., Jr., J.L. Tank, and M.F. Dybdahl. 2003. Exotic snails dominate nitrogen and carbon cycling in a highly productive stream. Frontiers in Ecology and the Environment 1:407-411.

Harried, B., K. Fischer, K.E. Perez, and G.J. Sandland. 2015. Assessing infection patterns in Chinese mystery snails from Wisconsin, USA using field and laboratory approaches. Aquatic Invasions 10:169-175.

Hendrickx, J.P., R.G. Creese, and P.E. Gribben. 2015. Impacts of a non-native gastropod with a limited distribution; less conspicuous invaders matter too. Marine Ecology Progress Series 537:151-162.

Karatayev, A.Y., S.E. Mastitsky, L.E. Burlakova, V.A. Karatayev, M.M. Hajduk, and D.B. Conn. 2012. Exotic mollusks in the Great Lakes host epizootically important trematodes. Journal of Shellfish Research 31:885-894.

Kipp, R.M., A.J. Benson, J. Larson, and A. Fusaro. 2017. Radix auricularia. USGS Nonindigenous Aquatic Species Database, Gainesville, FL; [accessed 4 May 2017]. http://nas.er.usgs.gov/queries/factsheet.aspx? SpeciesID $=1012$

Kolarova, L., P. Horak, and J. Sitko. 1997. Cercarial dermatitis in focus: schistosomes in the Czech Republic. Helminthologia 34:127-139.

LadD, H.L.A., AND D.L. Rogowski. 2012. Egg predation and parasite prevalence in the invasive freshwater snail, Melanoides turberculata (Muller, 1774) in a west Texas spring system. Aquatic Invasions 7: 287-290.

Larson, M.D., AND A.R. BLACK. 2016. Assessing interactions among native snails and the invasive New Zealand mud snail, Potamopyrgus antipodarum, using grazing experiments and stable isotope analysis. Hydrobiologia 763:147-159.

Lydeard, C., R.H. Cowie, W.F. Ponder, A.E. Bogan, P. Bouchet, S.A. Clark, K.S. Cummings, T.J. Frest, O. Gargominy, and D.G. Herbert, et al. 2004. The global decline of nonmarine mollusks. BioScience 54:321-330.

Mastitsky, S.E., A.Y. Karatayev, L.E. BurLakova, and D.P. MolLOy. 2010. Parasites of exotic species in invaded areas: does lower diversity mean lower epizootic impacts? Diversity and Distributions 16:798-803.

Riley, L.A., M.F. Dybdahl, and R.O. Hall JR. 2008. Invasive species impact: asymmetric interactions between invasive and endemic freshwater snails. Journal of the North American Benthological Society $27: 509-520$

Roy, H.E., AND L.J. LAwSON-HANDLEy. 2012. Networking: a community approach to invaders and their parasites. Functional Ecology 26:1238-1248.

SCHELL, S.C. 1970. How to know the trematodes. WMC Brown Company Publishers, Dubuque, IA.

SPYRA, A. 2010. Environmental factors influencing the occurrence of freshwater snails in woodland water bodies. Biologia 65:697-703.

Strayer, D.L. 1999. Effects of alien species on freshwater mollusks in North America. Journal of the North American Benthological Society 18:74-98. 
Torchin, M.E., And C.E. Mitchell. 2004. Parasites, pathogens, and invasions by plants and animals. Frontiers in Ecology and the Environment 2:183-190.

Vilà, M., J.L. Maron, and L. Marco. 2005. Evidence for the enemy release hypothesis in Hypericum perforatum. Oecologia 142:474-479.

VINARSKI, M.V., AND E.A. SERBINA. 2012. Distribution and quantitative characteristics of common species of pond snails of the subgenera Peregriana and Radix (Mollusca: Gastropoda: Lymnaeidae) in waterbodies of the south of Western Siberia. Inland Water Biology 5:192-198. von OHeimb, P.V., L. LANDler, and K.C.M. von OHeimb. 2016. Cold snails in hot springs: observations from Patagonia and the Tibetan Plateau. Malacologia 59: 313-320.

ZвiKowsKa, E. 2004. Infection of snails with bird schistosomes and the threat of swimmer's itch in selected Polish lakes. Parasitological Research 92:30-35.

Received 15 September 2017 Revised 23 January 2018 Accepted 24 January 2018 Published online 27 March 2018 